\title{
Effects of Light on Secondary Metabolites in Selected Leafy Greens: A Review
}

\author{
Felix Thoma*, Annette Somborn-Schulz, Dennis Schlehuber, Volkmar Keuter and \\ Görge Deerberg
}

Fraunhofer Institute for Environmental, Safety, and Energy Technologies UMSICHT, Oberhausen, Germany

OPEN ACCESS

Edited by: Rita Maria Zrenner, Leibniz Institute of Vegetable and Ornamental Crops, Germany

Reviewed by:

Matt Jones, University of Glasgow, United Kingdom Nieves Goicoechea,

University of Navarra, Spain

${ }^{*}$ Correspondence:

Felix Thoma

felix.thoma@umsicht.fraunhofer.de; felixneun9@gmail.com

Specialty section:

This article was submitted to

Plant Metabolism and Chemodiversity,

a section of the journal

Frontiers in Plant Science

Received: 05 September 2019

Accepted: 02 April 2020

Published: 24 April 2020

Citation:

Thoma F, Somborn-Schulz A

Schlehuber $D$, Keuter $V$ and

Deerberg G (2020) Effects of Light on

Secondary Metabolites in Selected

Leafy Greens: A Review.

Front. Plant Sci. 11:497.

doi: 10.3389/fp/s.2020.00497
In contrast to the primary metabolism, responsible for essential synthesis mechanisms and mass balance in plants, the secondary metabolism is not of particular importance for each cell but for the plant organism as its whole. Most of these metabolites show antioxidant properties and are beneficial for human health. In order to affect accumulation of those metabolites, light is an essential factor. It is possible to select various combinations of light intensity and light quality to address corresponding photoreceptors and synthesis. However, the plethora of additional variables considering environmental conditions such as temperature, relative humidity or cultivation method complicate defining specific "light recipes". This review summarizes experiments dealing with consumable leafy greens such as lettuce or basil and the enhancement of three selected metabolites - anthocyanins, carotenoids and flavonols.

Keywords: leafy green, secondary metabolite, flavonol, anthocyanin, carotenoid, light, photoreceptor

\section{INTRODUCTION}

Light greatly affects the biosynthesis and accumulation of various secondary plant metabolites that are crucial for crop quality (Siddiqui and Prasad, 2017). In contrast to primary metabolites, secondary metabolites such as anthocyanins, carotenoids or flavonols are minor compounds in plants occurring in low concentrations. They are not essential for life but play a major role in the plants fitness for survival (Pagare et al., 2015) and occur in most fruits and vegetables (Brglez Mojzer et al., 2016). Typical functions are cell pigmentation in order to attract pollinators and seed dispersers or protection against UV radiation or other abiotic and biotic stresses (Samanta et al., 2011; Mosadegh et al., 2018). In humans, they display various beneficial health effects. Due to their antioxidant activity, many of them show anti-microbial, anti-inflammatory and anti-allergic effects and are able to prevent diseases (Pedro et al., 2016; Lu et al., 2017).

The biosynthesis and accumulation of those secondary metabolites is mainly triggered through light. Photoreceptors are linked to signaling pathways and lead to gene expression changes when being activated by photons. The combination of a photoreceptor protein and a chromophore defines the light absorbing properties (Tilbrook et al., 2013; Folta and Carvalho, 2015). Absorption bands of essential photoreceptors and their affected quantities and processes are shown in Figure 1. In general, only a small fraction of absorbed photons is used for activating photoreceptors compared to those used for photosynthesis (Schopfer and Brennicke, 2010).

There are three main variables considering light requirements in horticulture: light quality, light quantity and photoperiodism (Kozai et al., 2016). In terms of light quality, various spectral composition having either narrow peaks or a smooth broadband spectrum can be generated with 


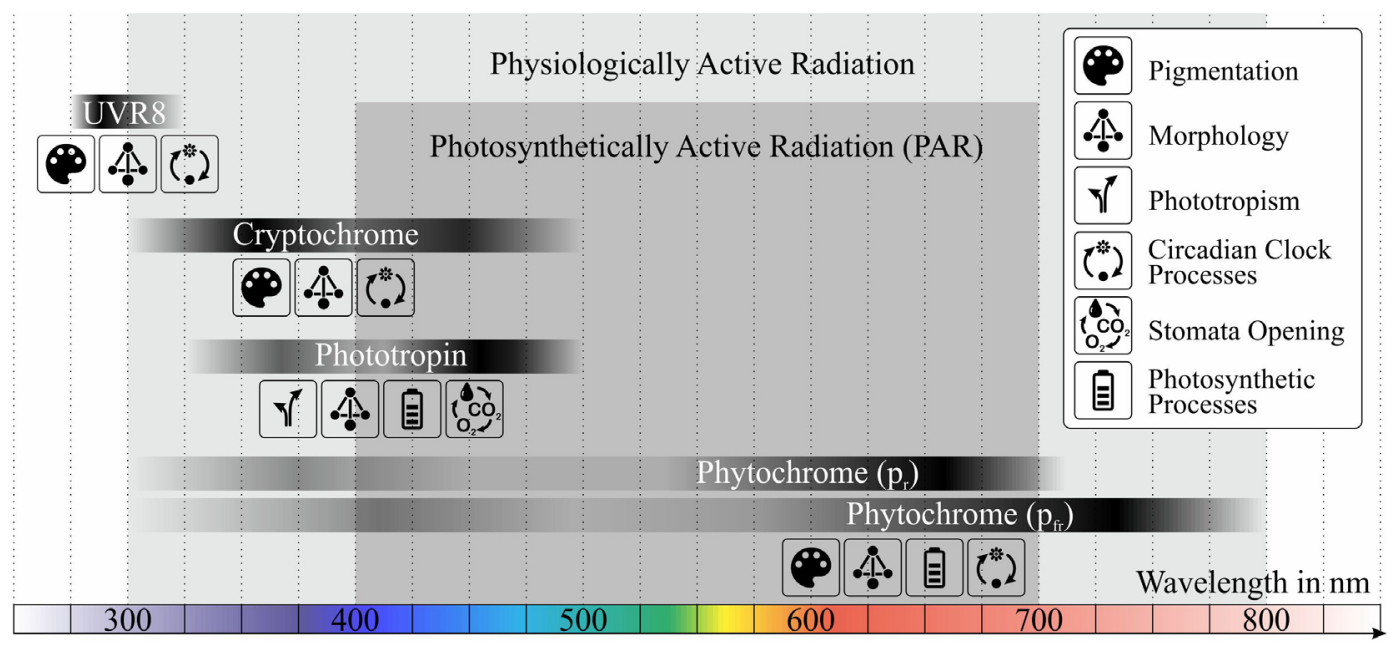

FIGURE 1 | Absorption bands of photoreceptors in plants and their affected quantities or processes, data obtained from Casal (2000), Schopfer and Brennicke (2010), and Folta and Carvalho (2015). In order to address secondary metabolites in plants, photosynthetically active radiation (PAR) is not sufficient, but a wider wavelength range (physiologically active radiation) must be considered.

either LED fixtures, HPSL (high pressure sodium lamp) or other light sources. Regarding light quantity, modern light sources are able to exceed the light saturation point (PPFD at which net photosynthetic rate per unit leaf area becomes maximum) in leafy greens, which is in general less than $1000 \mu \mathrm{mol} / \mathrm{m}^{2} / \mathrm{s}$ (Kozai et al., 2016). In terms of photoperoidism, not only the ratio of day and night period, but also supplemental exposure periods are possible. With these three variables the amount of realizable light settings is almost infinite.

When talking about lighting in horticulture, it is common to use units adapted to plants and photosynthesis. PAR (photosynthetically active radiation) is responsible for photosynthesis in plants and is defined as the wavelength range between 400 and $700 \mathrm{~nm}$ (Figure 1). The PPFD (photosynthetic photon flux density) is the integral of the irradiation $\mathrm{E}$ from 400 to $700 \mathrm{~nm}$ weighted with the wavelength $\lambda$ and a factor.

$$
P P F D=\int_{400}^{700} E_{\lambda} \times \lambda \times 0.00836 d \lambda
$$

The factor results from the unit $\mu \mathrm{mol} / \mathrm{m}^{2} / \mathrm{s}$ and its connection to the Avogadro constant, which indicates that not the energy of photons but the number of photons is crucial (McCree, 1972; Tazawa, 1999).

Besides radiation between 400 and $700 \mathrm{~nm}$, also photons with lower or higher wavelengths contribute partly to photosynthesis, morphologic processes or the synthesis of secondary metabolites (Tazawa, 1999). For those physiological processes, the wavelength range between 300 and $800 \mathrm{~nm}$ is defined as the less well-known physiologically active radiation (see Figure 1). Those definitions should be handled with care since UV light for example is not included in the PAR domain and does not contribute to the total PPFD but can still be stated in $\mu \mathrm{mol} / \mathrm{m}^{2} / \mathrm{s}$.

Additionally to the three light variables mentioned above (light quality, light quantity and photoperiodism), further environmental grow parameters, such as temperature, relative humidity or irrigation are variable and require specific settings depending on plant species and cultivars. The amount of variables opens a large parametric space, which complicates a comparability of studies and experiments regarding the influence of light on the accumulation of secondary metabolites. This review summarizes the results of various studies with the aim of showing trends and parallels regarding the effects of certain light scenarios on the accumulation of three selected secondary metabolites in leafy greens. For this purpose, articles containing "leafy," "microgreen," "salad," "lettuce," "basil," "spinach," "parsley," "rocket," "chard” or "lovage” were considered.

\section{PHOTORECEPTOR PROTEINS}

The following section gives an overview on the mechanisms and main tasks of the four major photoreceptors in plants and their absorption bands (see Figure 1). These receptors absorb photons not only in the PAR domain, but also wavelengths in the UV and far-red region. They interact with further signal transduction elements and are responsible for triggering different processes, such as the biosynthesis of secondary metabolites (Frankhauser and Chory, 1997).

\section{Cryptochrome}

The absorption of the protein cryptochrome peaks in the UV$\mathrm{A}$ and blue light domain between 340 and $520 \mathrm{~nm}$ (Figure 1; Schopfer and Brennicke, 2010). Due to the non-covalent bond of cry to one of two possible chromophores, two absorption maxima exist. The first maximum at $375 \mathrm{~nm}$ results from the chromophore 5,10-methenyltetrahydrofolic acid (MTHF), the second at $450 \mathrm{~nm}$ from the chromophore flavin [in the form of flavin adenine dinucleotide (FAD)] (Fuller et al., 2016). 
Dependent on transient redox state, the flavin chromophore shows different absorption properties. When being exposed to blue light, it shifts to a semi-reduced form with its absorption in the green and yellow domain. Being then illuminated with green or yellow light, the cryptochrome gets inactivated (Folta and Maruhnich, 2007). It was shown, that green light is able to reverse the effects of blue light, such as anthocyanin accumulation, inhibition of extension growth or stimulation of stomata opening (Folta, 2004; Bouly et al., 2007; Wang and Folta, 2013). Additionally, flowering is inhibited, which is known to be induced by blue light, mainly through cry2 (Folta and Carvalho, 2015). Besides morphologic aspects, such as plant or root growth, fruit size or stem elongation, cryptochrome is responsible for regulating processes linked to the circadian clock, like seedling development, guard cell opening, photoperiodic flowering control or de-etiolation (greening after period of darkness) (Ahmad and Cashmore, 1993; Guo et al., 1998; Devlin, 2000; Folta and Spalding, 2001; Mao et al., 2005; Fox et al., 2012). The use of knock-out mutants regarding cryptochrome in plants restricts mainly on Arabidopsis (Kang and Ni, 2006; Popov et al., 2010). Barrero et al. (2014) demonstrated by using a knockdown of cryla/b and cry 2 mRNA, that cry1 is responsible for grain germination in barley. A rough separation with other blue light receptors can also be made by changing the light intensity, since cryptochrome tends to have high-fluence-rate responses (Folta and Carvalho, 2015). Due to lower levels of blue light below canopies cryptochrome also shows a phototropic response (Goyal et al., 2016). Additionally, Fox et al. (2012) showed that the accumulation of anthocyanins is controlled by cryptochrome.

\section{Phytochrome}

Phytochrome, a hydrophilic protein, is responsible for the absorption of light mainly in the red/far-red region around $665 \mathrm{~nm}\left(\mathrm{P}_{\mathrm{r}}\right)$ and $730 \mathrm{~nm}\left(\mathrm{P}_{\mathrm{fr}}\right)$, but also in blue/near-UV region (Figure 1). It shows a large range in sensitivity (from moonlight to full sunlight) and controls morphologic and physiologic parameters, but also pigmentation. phyA and phyB are the best-known phytochromes, however, stability inside the cell and functionality differ between them. For both types, $\mathrm{P}_{\mathrm{r}}$ is generated in darkness and converts reversible to $\mathrm{P}_{\mathrm{fr}}$ when illuminated (Deutsches Institut für Normung, 2018). When light stimulates phytochrome, events in cytoplasm and nucleus are initiated. Many of them are related to alterations in hormone levels such as gibberellins and auxins (plant hormones concerning growth), ethylene, jasmonates (plant hormone concerning growth and photosynthesis) and abscisic acid (ABA) (plant hormone concerning development, control of organ size, stomatal closure) (Casal, 2000; Schopfer and Brennicke, 2010).

\section{Phototropin}

The protein phototropin absorbs light in the range between 340 and $520 \mathrm{~nm}$ (Figure 1) and is mainly responsible for a direct or indirect optimization of photosynthesis (e.g. phototactic orientation of chloroplasts) (Schopfer and Brennicke, 2010). phot1 acts under low light intensity (leaf expansion/position) and phot 2 is activated and acts redundantly with phot 1 under higher light intensities (Takemiya et al., 2005). As the name implies, phototropin is responsible for phototropism and the optimization of plant growth and development for better photosynthesis. Especially through low fluence in the blue light domain, phototropin suppresses leaf curling (promoted by phyB), which results in flatter leaves and thus a higher light absorption (Folta and Carvalho, 2015). Additionally, phototropin partially controls the opening of stomata und thus transpiration (Schopfer and Brennicke, 2010).

\section{UVR8}

Considering the UV range from 280 to $350 \mathrm{~nm}$, the protein UVR8 shows maximum absorption (Figure 1; Schopfer and Brennicke, 2010). Since UV-radiation - especially at short wavelengths - is able to damage DNA or proteins by the generation of reactive oxygen species (ROS), plants have certain damage-repair mechanisms and UV absorbing pigments. UVR8 generates gene expressions that induce the accumulation of such protective pigments (e.g. anthocyanins). Furthermore, UVR8 influences plant architecture in a way that plants grow more compact concerning stem elongation and leaf expansion. UVR8 enables producers the control of growth without photosynthetic radiation (400-700 nm) (Casal, 2000; Cope and Bugbee, 2013; Coffey et al., 2017).

\section{EFFECTS OF LIGHT ON SECONDARY METABOLITES}

The following sections states the effect of light on three representative groups of secondary metabolites - anthocyanins, carotenoids and flavonols. Tables 1-3 summarizes those studies regarding fixed parameters, variable light parameters and their qualitative effect on the investigated metabolite in selected plants.

\section{Anthocyanins}

So far, 35 different anthocyanidins and more than 600 anthocyanins (glycoside form of anthocyanidins) are known. Six anthocyanidins (cyanidin 50\%, delphinidin 12\%, pelargonidin $12 \%$, peonidin $7 \%$, petunidin $7 \%$ and malvidin $7 \%$ ) are common in plants (Kong et al., 2003; Andersen and Jordheim, 2010). The glycoside derivatives of the three non-methylated anthocyanidins (cyanidin, delphinidin and pelargonidin) are found in $80 \%$ of pigmented leaves, 69\% in fruits and 50\% in flowers (Evans, 1991). Additionally, grains and roots can contain anthocyanins (Khoo et al., 2017). Produced in the cytoplasm, anthocyanin molecules accumulate in the vacuole, where they are solved in the cell sap (Schopfer and Brennicke, 2010). They show effects on growth and feeding behavior of insects, protect the plant against UV radiation or act as attractor to animals in order to spread seeds and pollen (Onyilagha et al., 2004; Khalid et al., 2019). Due to their ability to donate a hydrogen atom (oxidation) e.g. to reactive free radicals, anthocyanins are decent antioxidants (CastañedaOvando et al., 2009). They have shown a higher antioxidant activity than vitamins C and E (Bagchi et al., 1998). Further health benefits of anthocyanins are antiangiogenesis, prevention of CVD, anticancer, antidiabetes, improved visual health, antiobesity, antimicrobial, and neuroprotection (Khoo et al., 2017; 
TABLE 1 | Relative accumulation of anthocyanins after different treatments.

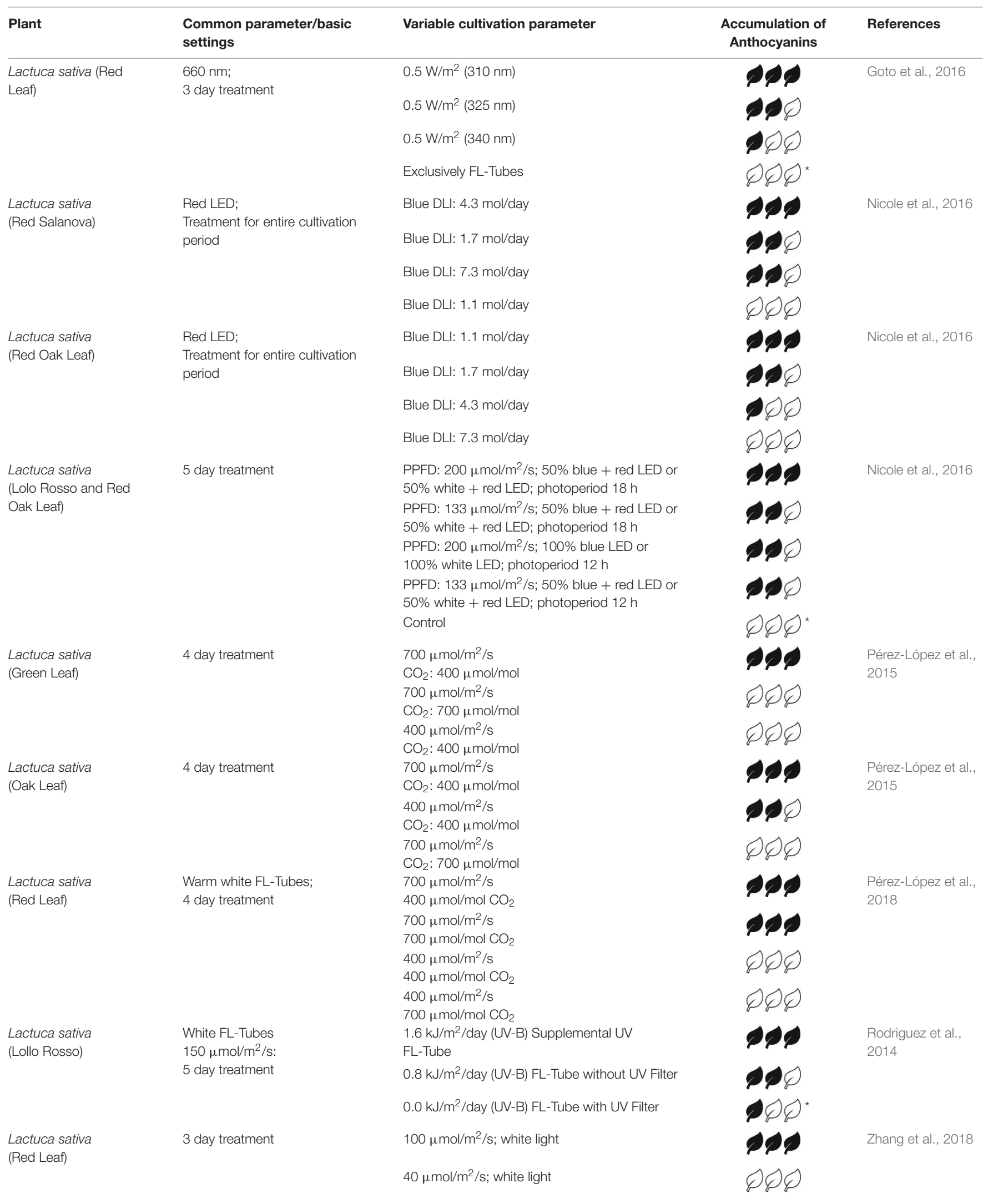


TABLE 1 | Continued

\begin{tabular}{|c|c|c|c|c|}
\hline Plant & $\begin{array}{l}\text { Common parameter/basic } \\
\text { settings }\end{array}$ & Variable cultivation parameter & $\begin{array}{l}\text { Accumulation of } \\
\text { Anthocyanins }\end{array}$ & References \\
\hline $\begin{array}{l}\text { Lactuca sativa } \\
\text { (Red Romaine) }\end{array}$ & HPSL + Metal Halide HIDL & $\begin{array}{l}420 \mu \mathrm{mol} / \mathrm{m}^{2} / \mathrm{s} \\
225 \mu \mathrm{mol} / \mathrm{m}^{2} / \mathrm{s}\end{array}$ & & Massa et al., 2015 \\
\hline $\begin{array}{l}\text { Ocimum basilicum } \\
\text { (Red Leaf) }\end{array}$ & $\begin{array}{l}\text { PPFD: } 120 \mu \mathrm{mol} / \mathrm{m}^{2} / \mathrm{s} \text {; } \\
\text { Treatment for entire cultivation } \\
\text { period }\end{array}$ & $\begin{array}{l}\text { Blue:red ratio 1:2 } \\
\text { Blue:red ratio 2:1 } \\
\text { Blue:red ratio 1:1 } \\
\text { White LED }\end{array}$ & 4 & Lobiuc et al., 2017 \\
\hline $\begin{array}{l}\text { Ocimum basilicum } \\
\text { (Sweet Genovese and } \\
\text { Dark Opal) }\end{array}$ & $\begin{array}{l}\text { PPFD: } 125 \mu \mathrm{mol} / \mathrm{m}^{2} / \mathrm{s} \text {; } \\
\text { Greenhouse }\end{array}$ & $\begin{array}{l}\text { HPSL } \\
\text { HPSL }+390 \mathrm{~nm} \text { for } 14 \text { days before harvest } \\
\text { HPSL }+390 \mathrm{~nm} \text { for } 7 \text { days before harvest } \\
\text { HPSL }+390 \mathrm{~nm} \text { for } 1 \text { day before harvest }\end{array}$ & 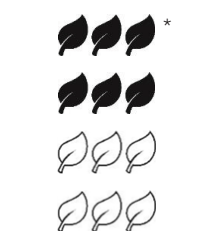 & $\begin{array}{l}\text { Vaštakaitë et al., } \\
2015 a\end{array}$ \\
\hline $\begin{array}{l}\text { Ocimum basilicum } \\
\text { (Sweet Genovese, } \\
\text { Microgreens) }\end{array}$ & $\begin{array}{l}\text { PPFD: } 300 \mu \mathrm{mol} / \mathrm{m}^{2} / \mathrm{s} ; \\
21 \mu \mathrm{mol} / \mathrm{m}^{2} / \mathrm{s}(447 \mathrm{~nm})+ \\
122 \mu \mathrm{mol} / \mathrm{m}^{2} / \mathrm{s}(638 \mathrm{~nm})+ \\
155 \mu \mathrm{mol} / \mathrm{m}^{2} / \mathrm{s}(665 \mathrm{~nm})+ \\
2 \mu \mathrm{mol} / \mathrm{m}^{2} / \mathrm{s}(731 \mathrm{~nm}) ; \\
\text { Treatment for entire cultivation } \\
\text { period }\end{array}$ & $\begin{array}{l}\text { No supplemental UV } \\
12 \mu \mathrm{mol} / \mathrm{m}^{2} / \mathrm{s}(366 \mathrm{~nm}) \\
12 \mu \mathrm{mol} / \mathrm{m}^{2} / \mathrm{s}(402 \mathrm{~nm}) \\
12 \mu \mathrm{mol} / \mathrm{m}^{2} / \mathrm{s}(390 \mathrm{~nm}) \\
6 \mu \mathrm{mol} / \mathrm{m}^{2} / \mathrm{s}(390 \mathrm{~nm}) \\
\text { No supplemental UV } \\
6 \mu \mathrm{mol} / \mathrm{m}^{2} / \mathrm{s}(366 \mathrm{~nm}) \\
6 \mu \mathrm{mol} / \mathrm{m}^{2} / \mathrm{s}(402 \mathrm{~nm})\end{array}$ & . & $\begin{array}{l}\text { Brazaitytë et al., } \\
2015\end{array}$ \\
\hline Ocimum basilicum & $\begin{array}{l}\text { FL-Tube Cool White; } \\
21 \text { day treatment }\end{array}$ & $\begin{array}{l}\text { PPFD: } 13 \mathrm{~mol} / \mathrm{m}^{2} / \mathrm{d} \\
\text { PPFD: } 17 \mathrm{~mol} / \mathrm{m}^{2} / \mathrm{d} \\
\text { PPFD: } 12 \mathrm{~mol} / \mathrm{m}^{2} / \mathrm{d} \\
\text { PPFD: } 18 \mathrm{~mol} / \mathrm{m}^{2} / \mathrm{d} \\
\text { PPFD: } 9 \mathrm{~mol} / \mathrm{m}^{2} / \mathrm{d}\end{array}$ & & Dou et al., 2018 \\
\hline $\begin{array}{l}\text { Valerianella locusta } \\
\text { (Holländischer) }\end{array}$ & $\begin{array}{l}\text { PPFD: } 200 \mu \mathrm{mol} / \mathrm{m}^{2} / \mathrm{s} \text {; } \\
\text { Greenhouse; } \\
\text { Treatment for entire cultivation } \\
\text { period }\end{array}$ & $\begin{array}{l}10 \% \text { blue }(449 \mathrm{~nm})+90 \% \text { red }(660 \mathrm{~nm}) \\
\text { HPSL } \\
30 \% \text { blue }(449 \mathrm{~nm})+70 \% \text { red }(660 \mathrm{~nm}) \\
20 \% \text { blue }(449 \mathrm{~nm})+80 \% \text { red }(660 \mathrm{~nm}) \\
0 \% \text { blue }(449 \mathrm{~nm})+100 \% \text { red }(660 \mathrm{~nm})\end{array}$ & & $\begin{array}{l}\text { Długosz- } \\
\text { Grochowska et al., } \\
2017\end{array}$ \\
\hline
\end{tabular}


TABLE 1 | Continued

\begin{tabular}{llll}
\hline Plant & $\begin{array}{l}\text { Common parameter/basic } \\
\text { settings }\end{array}$ & Variable cultivation parameter & $\begin{array}{c}\text { Accumulation of } \\
\text { Anthocyanins }\end{array}$ \\
\hline $\begin{array}{l}\text { Valerianella locusta } \\
\text { (Noordhollandse) }\end{array}$ & $\begin{array}{l}\text { PPFD: } 200 \mu \mathrm{mol} / \mathrm{m}^{2} / \mathrm{s} ; \\
\text { Greenhouse; } \\
\text { Treatment for entire cultivation } \\
\text { period }\end{array}$ & $0 \%$ blue $(449 \mathrm{~nm})+100 \%$ red $(660 \mathrm{~nm})$ & $10 \%$ blue $(449 \mathrm{~nm})+90 \%$ red $(660 \mathrm{~nm})$ \\
& $20 \%$ blue $(449 \mathrm{~nm})+80 \%$ red $(660 \mathrm{~nm})$ & $30 \%$ blue $(449 \mathrm{~nm})+70 \%$ red $(660 \mathrm{~nm})$ & Długosz- \\
& HPSL &
\end{tabular}

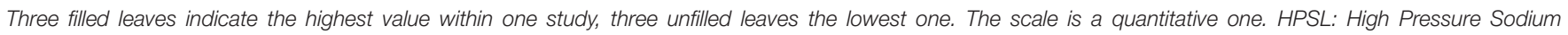

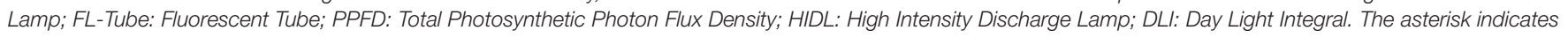
the control group, if available.

Khalid et al., 2019). In general, anthocyanins show a low bioavailability, which means only a small amount is absorbed into the blood cycle during digestion. Khoo et al. (2017) also summarize that increased consumption may enhance their efficacy, however, side effects of overconsumption are not investigated yet. In 2001, Bieza and Lois (2001) reported a protecting effect of anthocyanins in Arabidopsis uvt1 mutants (hypersensitive to UV) against UV radiation. The extract of UV irradiated leaves absorbs more light between 300 and $400 \mathrm{~nm}$ than the non-irradiated one. The exposure induces the development of UV protecting anthocyanins (Bieza and Lois, 2001).

In their review from 2015, Bian et al. (2015) summarize that especially UV light optimizes the accumulation of phenolic compounds in general. In particular, the concentration of anthocyanins is affected by mainly blue, UV-A and UV-B light. Considering Lactuca sativa (green leaf), Rodriguez et al. (2014) found that the use of UV Fluorescent-Tubes (FL-Tubes) supplementary to sunlight results in a maximum of anthocyanins content. Similarly, Goto et al. (2016) obtained an increase in anthocyanins exposing red leaf lettuce to three different UV wavelengths in the order $310 \mathrm{~nm}>325 \mathrm{~nm}>340 \mathrm{~nm}$. In contrast to that, Vaštakaitë et al. (2015a) showed that anthocyanin content in basil was highest without UV radiation. Similarly, exposing basil to three supplementary UV wavelengths at two intensities, the group of Brazaitytë et al. (2015) found highest content of anthocyanins in the control group.

Since not only UVR8 and cryptochrome but also low amounts of either phyA or phyB are relevant for the accumulation of anthocyanins, wavelengths beyond UV also show effects. Considering the effect of blue light, the anthocyanin index was dependent on variety, even between different red lettuce varieties. Red Oak lettuce showed maximum values at highest daily blue light integral (BDLI at $7.3 \mathrm{~mol} /$ day) and for Red Salanova lettuce the maximum anthocyanin index occurred at a BDLI of $4.3 \mathrm{~mol} /$ day. Both varieties had its minimum at the lowest BDLI of $1.1 \mathrm{~mol} /$ day (Nicole et al., 2016). A blue:red ratio of 1:2 for Ocimum basilicum showed best results compared to other ratios (Lobiuc et al., 2017). Similar results obtained the group of Vaštakait, but using two red channels (Vaštakaitë et al., 2015b). For two cultivars of Valerianella locusta the maximum accumulation of anthocyanins was determined at a blue:red ratio of 1:9 and only red light. However, for one cultivar the control group under HPSL also showed maximum values whereas the control group of the second cultivar had the lowest content of anthocyanins (Długosz-Grochowska et al., 2017). Far-red light reduces the synthesis of anthocyanins (Bian et al., 2015).

Besides light quality, light intensity and photoperiodism where investigated in various studies. In general, a light intensity between 200 and $300 \mu \mathrm{mol} / \mathrm{m}^{2} / \mathrm{s}$ is suitable for plants grown in controlled environments (Bian et al., 2015). In two studies Pérez-López et al. $(2015,2018)$ showed that the combination of a high light intensity and low $\mathrm{CO}_{2}$ values is a good condition for the accumulation of anthocyanins not only in green but also in red leaf lettuce. Nicole et al. (2016) increased the anthocyanin index in Red Oak and Red Salanova lettuce having a long photoperiod of $18 \mathrm{~h}$ a day compared to $12 \mathrm{~h}$ a day and a PPFD of $200 \mu \mathrm{mol} / \mathrm{m}^{2} / \mathrm{s}$. Both varieties showed similar behavior considering changes in photoperiodism and DLI (day light integral) differing only in absolute anthocyanin index values. Under cool white FL-Tubes the anthocyanin content of basil was highest at a DLI of 13 and $17 \mathrm{~mol} / \mathrm{m}^{2} / \mathrm{d}$ (Dou et al., 2018).

In general one can say that supplementary UV-A and UV-B light induces the synthesis of anthocyanins in many leafy greens, especially in red leafy greens. One exception is basil, where the addition of UV light and the accumulation of anthocyanins correlates negatively. A blue:red ratio between 1:1.5 and 1:2 serves as a reliable basis concerning the accumulation of anthocyanins in leafy greens. Comparing studies dealing with basil, similarities in applying a low blue:red ratio as optimal light condition can be observed. However, Vaštakaitë et al. (2015b) showed, that no blue light at all resulted in low anthocyanin levels (Lobiuc et al., 2017). For Valerianella locusta (var. Holländischer), similar effects were observed, whereas var. Noordhollandse showed highest contents without blue light (Długosz-Grochowska et al., 2017). This indicates that even within different varieties optimal light conditions differ. For detailed information see Table 1.

\section{Carotenoids}

Carotenoids fulfill two major functions: on the one hand, they harvest light and protect the plant from high exposures (xanthophyll cycle), and on the other hand, they attract animals in order to spread the plants seeds and pollen. Carotenoids 
TABLE 2 | Relative accumulation of carotenoids after different treatments.

\begin{tabular}{|c|c|c|c|c|}
\hline Plant & $\begin{array}{l}\text { Common parameter/basic } \\
\text { settings }\end{array}$ & Variable cultivation parameter & $\begin{array}{l}\text { Accumulation of } \\
\text { Carotenoids }\end{array}$ & References \\
\hline $\begin{array}{l}\text { Beta vulgaris } \\
\text { (Cicla) }\end{array}$ & Sunlight in greenhouse & $\begin{array}{l}\text { PPFD: } 278 \mu \mathrm{mol} / \mathrm{m}^{2} / \mathrm{s} \text {; red colored filter } \\
\text { PPFD: } 256 \mu \mathrm{mol} / \mathrm{m}^{2} / \mathrm{s} \text {; transparent filter } \\
\text { PPFD: } 185 \mu \mathrm{mol} / \mathrm{m}^{2} / \mathrm{s} \text {; blue colored filter } \\
\text { PPFD: } 234 \mu \mathrm{mol} / \mathrm{m}^{2} / \mathrm{s} \text {; yellow colored filter } \\
\text { PPFD: } 261 \mu \mathrm{mol} / \mathrm{m}^{2} / \mathrm{s} \text {; green colored filter }\end{array}$ & 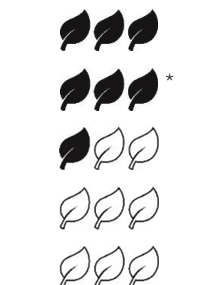 & Casierra-Posada et al., 2015 \\
\hline $\begin{array}{l}\text { Brassica oleracea } \\
\text { (Green, Microgreen) }\end{array}$ & $\begin{array}{l}\text { PPFD: } 300 \mu \mathrm{mol} / \mathrm{m}^{2} / \mathrm{s} \\
42 \mu \mathrm{mol} / \mathrm{m}^{2} / \mathrm{s} \\
(447 \mathrm{~nm})+89 \mu \mathrm{mol} / \mathrm{m}^{2} / \mathrm{s} \\
(638 \mathrm{~nm})+150 \mu \mathrm{mol} / \mathrm{m}^{2} / \mathrm{s} \\
(665 \mathrm{~nm})+4 \mu \mathrm{mol} / \mathrm{m}^{2} / \mathrm{s}(731 \mathrm{~nm})\end{array}$ & $\begin{array}{l}15 \mu \mathrm{mol} / \mathrm{m}^{2} / \mathrm{s}(638 \mathrm{~nm}) \\
15 \mu \mathrm{mol} / \mathrm{m}^{2} / \mathrm{s}(622 \mathrm{~nm}) \\
15 \mu \mathrm{mol} / \mathrm{m}^{2} / \mathrm{s}(520 \mathrm{~nm}) \\
15 \mu \mathrm{mol} / \mathrm{m}^{2} / \mathrm{s}(595 \mathrm{~nm})\end{array}$ & 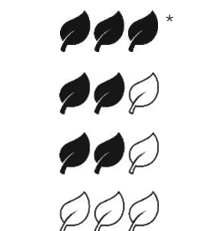 & Samuolienë et al., 2019 \\
\hline $\begin{array}{l}\text { Brassica rapa } \\
\text { (Japonica, Microgreen) }\end{array}$ & $\begin{array}{l}\text { PPFD: } 300 \mu \mathrm{mol} / \mathrm{m}^{2} / \mathrm{s} \\
42 \mu \mathrm{mol} / \mathrm{m}^{2} / \mathrm{s} \\
(447 \mathrm{~nm})+89 \mu \mathrm{mol} / \mathrm{m}^{2} / \mathrm{s} \\
(638 \mathrm{~nm})+150 \mu \mathrm{mol} / \mathrm{m}^{2} / \mathrm{s} \\
(665 \mathrm{~nm})+4 \mu \mathrm{mol} / \mathrm{m}^{2} / \mathrm{s}(731 \mathrm{~nm})\end{array}$ & $\begin{array}{l}15 \mu \mathrm{mol} / \mathrm{m}^{2} / \mathrm{s}(520 \mathrm{~nm}) \\
15 \mu \mathrm{mol} / \mathrm{m}^{2} / \mathrm{s}(595 \mathrm{~nm}) \\
15 \mu \mathrm{mol} / \mathrm{m}^{2} / \mathrm{s}(622 \mathrm{~nm}) \\
15 \mu \mathrm{mol} / \mathrm{m}^{2} / \mathrm{s}(638 \mathrm{~nm})\end{array}$ & 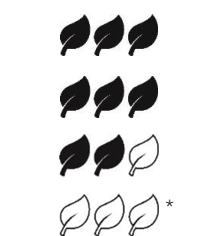 & Samuolienë et al., 2019 \\
\hline $\begin{array}{l}\text { Lactuca sativa } \\
\text { (Green Leaf) }\end{array}$ & $\begin{array}{l}20 \% \text { blue LED }+80 \% \text { red LED; } \\
30 \text { day treatment }\end{array}$ & $\begin{array}{l}\text { PPFD: } 140 \mu \mathrm{mol} / \mathrm{m}^{2} / \mathrm{s} \\
\text { PPFD: } 60 \mu \mathrm{mol} / \mathrm{m}^{2} / \mathrm{s} ; \\
\text { PPFD: } 220 \mu \mathrm{mol} / \mathrm{m}^{2} / \mathrm{s}\end{array}$ & & Fu et al., 2017 \\
\hline $\begin{array}{l}\text { Lactuca sativa } \\
\text { (Green Leaf) }\end{array}$ & PPFD: $300 \mu \mathrm{mol} / \mathrm{m}^{2} / \mathrm{s}$ & $\begin{array}{l}\text { 30\% (LED 460-475 nm) + 70\% (LED } \\
650-665 \mathrm{~nm}) \\
\text { 100\% (LED white 380-760 nm) } \\
\text { 100\% (LED 460-475 nm) } \\
\text { Greenhouse conditions } \\
\text { 100\% (LED 650-665 nm) }\end{array}$ & 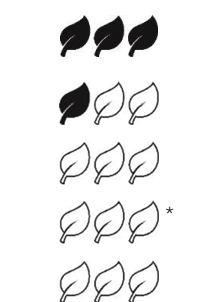 & Amoozgar et al., 2017 \\
\hline $\begin{array}{l}\text { Lactuca sativa } \\
\text { (Green Oak Leaf) }\end{array}$ & $\begin{array}{l}\text { PPFD: } 133 \mu \mathrm{mol} / \mathrm{m}^{2} / \mathrm{s} \text {; } \\
50 \text { day treatment }\end{array}$ & $\begin{array}{l}50 \% \text { red }(630 \mathrm{~nm})+50 \% \text { FL-Tube } \\
50 \% \text { blue }(460 \mathrm{~nm})+50 \% \text { FL-Tube } \\
50 \% \text { blue }(460 \mathrm{~nm})+50 \% \text { red }(630 \mathrm{~nm}) \\
100 \% \text { blue }(460 \mathrm{~nm}) \\
100 \% \text { FL-Tube } \\
100 \% \text { red }(630 \mathrm{~nm})\end{array}$ & & Chen et al., 2014 \\
\hline $\begin{array}{l}\text { Lactuca sativa } \\
\text { (Green Oak Leaf) }\end{array}$ & $\begin{array}{l}\text { PPFD: } 135 \mu \mathrm{mol} / \mathrm{m}^{2} / \mathrm{s} \text {; } \\
\text { LED; } \\
35 \text { day treatment }\end{array}$ & $\begin{array}{l}31 \mu \mathrm{mol} / \mathrm{m}^{2} / \mathrm{s}(450 \mathrm{~nm})+41 \mu \mathrm{mol} / \mathrm{m}^{2} / \mathrm{s} \\
(522 \mathrm{~nm})+11 \mu \mathrm{mol} / \mathrm{m}^{2} / \mathrm{s} \\
(596 \mathrm{~nm})+52 \mu \mathrm{mol} / \mathrm{m}^{2} / \mathrm{s}(660 \mathrm{~nm})\end{array}$ & & Chen et al., 2016 \\
\hline
\end{tabular}


TABLE 2 | Continued

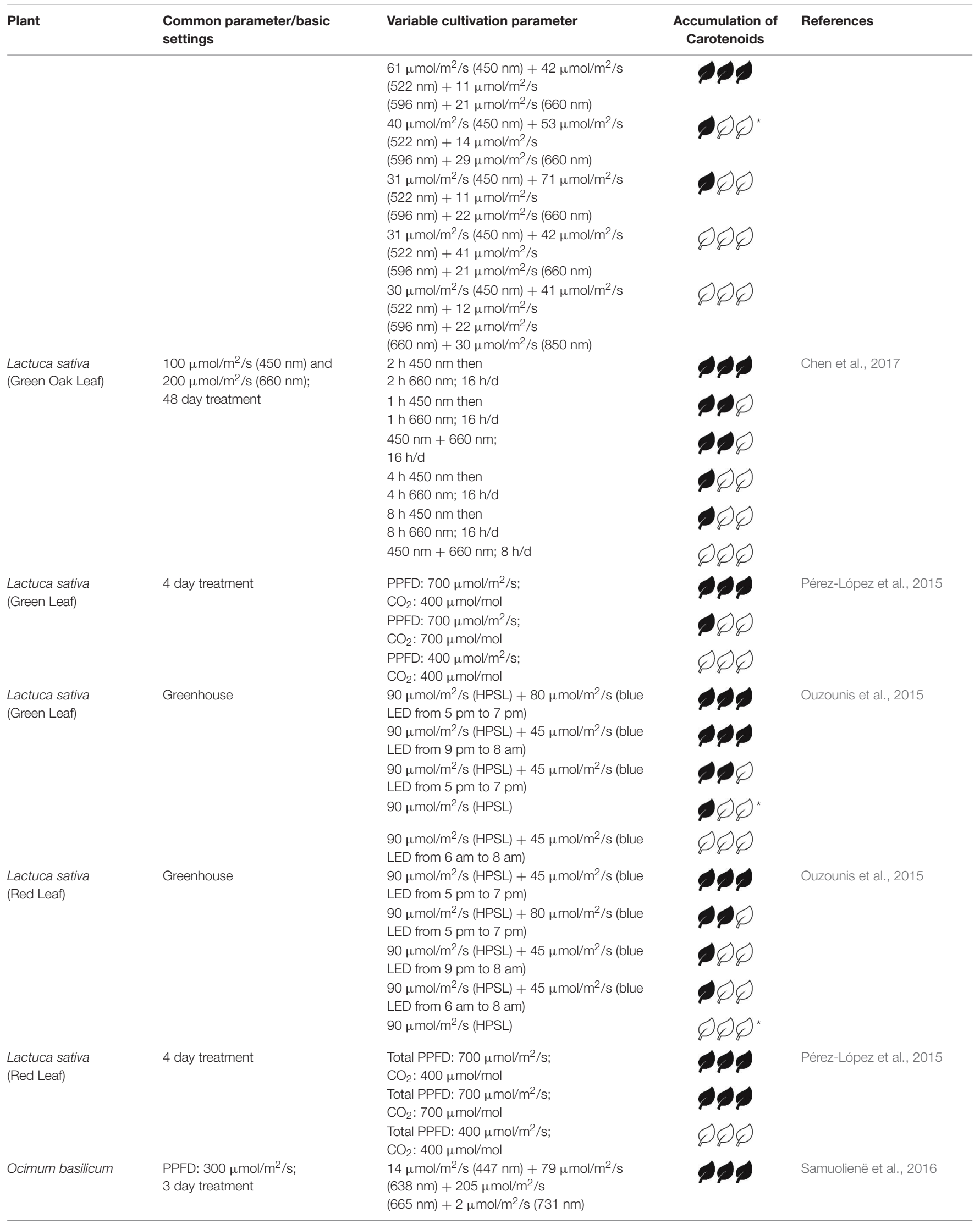


TABLE 2 | Continued

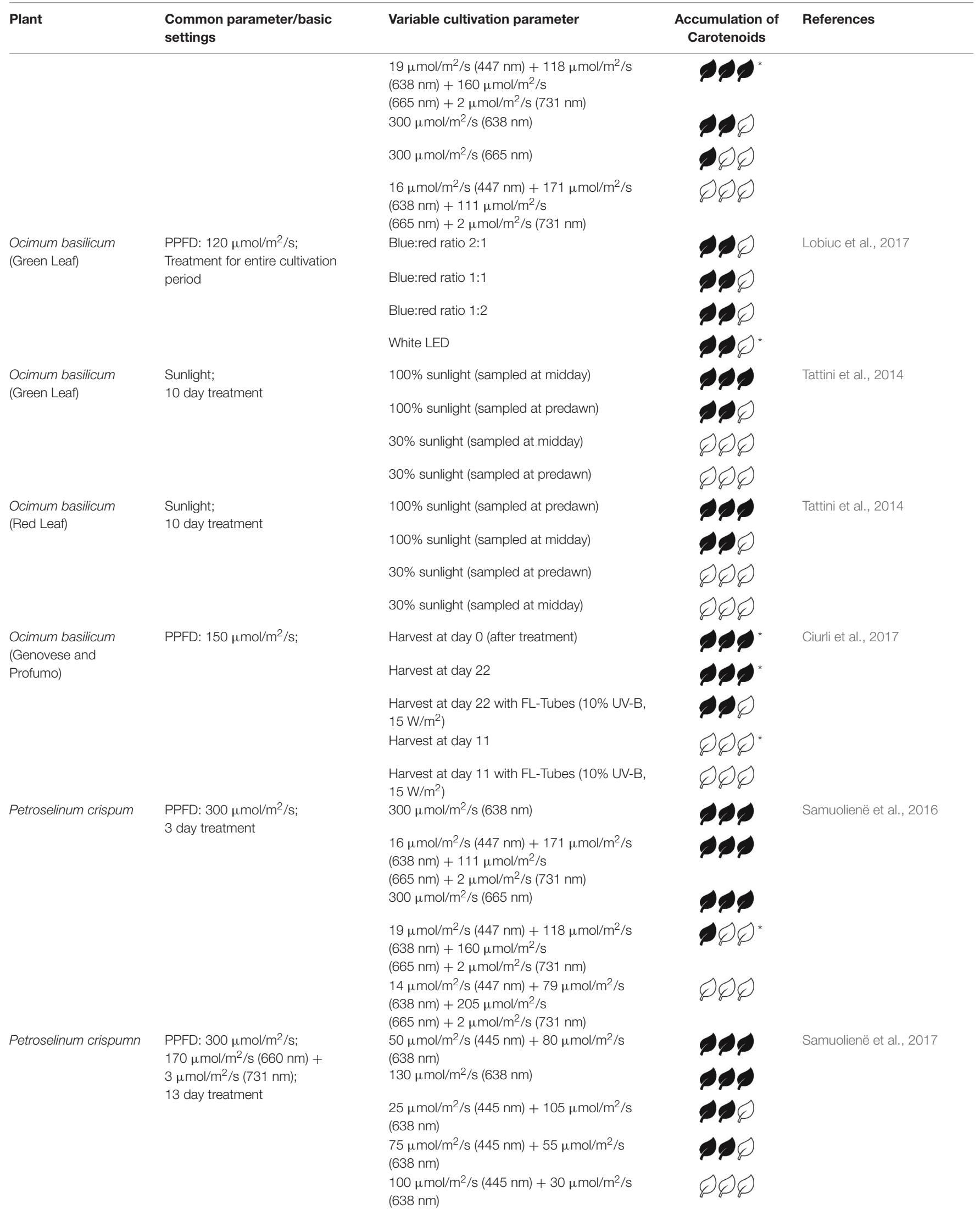


TABLE 2 | Continued

\begin{tabular}{|c|c|c|c|c|}
\hline Plant & $\begin{array}{l}\text { Common parameter/basic } \\
\text { settings }\end{array}$ & Variable cultivation parameter & $\begin{array}{l}\text { Accumulation of } \\
\text { Carotenoids }\end{array}$ & References \\
\hline Spinacia oleracea & $\begin{array}{l}\text { FL-Tubes; } \\
18 \text { day treatment }\end{array}$ & $\begin{array}{l}\text { PPFD: } 600 \mu \mathrm{mol} / \mathrm{m}^{2} / \mathrm{s} \\
\text { PPFD: } 300 \mu \mathrm{mol} / \mathrm{m}^{2} / \mathrm{s}\end{array}$ & & Esteban et al., 2014 \\
\hline $\begin{array}{l}\text { Valerianella locusta } \\
\text { (Holländischer) }\end{array}$ & $\begin{array}{l}\text { PPFD: } 200 \mu \mathrm{mol} / \mathrm{m}^{2} / \mathrm{s} \text {; } \\
\text { Greenhouse; } \\
\text { Treatment for entire cultivation } \\
\text { period }\end{array}$ & $\begin{array}{l}\text { HPSL } \\
20 \%(440 \mathrm{~nm})+80 \%(660 \mathrm{~nm}) \\
30 \%(440 \mathrm{~nm})+70 \%(660 \mathrm{~nm}) \\
10 \%(440 \mathrm{~nm})+90 \%(660 \mathrm{~nm}) \\
100 \%(660 \mathrm{~nm})\end{array}$ & & $\begin{array}{l}\text { Długosz-Grochowska et al., } \\
2017\end{array}$ \\
\hline $\begin{array}{l}\text { Valerianella locusta } \\
\text { (Noordhollandse) }\end{array}$ & $\begin{array}{l}\text { PPFD: } 200 \mu \mathrm{mol} / \mathrm{m}^{2} / \mathrm{s} \text {; } \\
\text { Greenhouse; } \\
\text { Treatment for entire cultivation } \\
\text { period }\end{array}$ & $\begin{array}{l}\text { HPSL } \\
30 \%(440 \mathrm{~nm})+70 \%(660 \mathrm{~nm}) \\
20 \%(440 \mathrm{~nm})+80 \%(660 \mathrm{~nm}) \\
10 \%(440 \mathrm{~nm})+90 \%(660 \mathrm{~nm}) \\
100 \%(660 \mathrm{~nm})\end{array}$ & & $\begin{array}{l}\text { Długosz-Grochowska et al., } \\
2017\end{array}$ \\
\hline
\end{tabular}

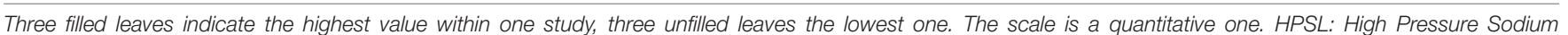

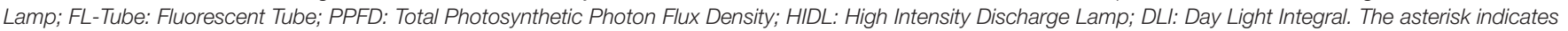
the control group, if available.

include two major sub-groups: carotenes ( $\alpha$-carotene, $\beta$-carotene, lycopene) and xanthophylls (lutein, zeaxanthin, etc.). Both are located in the thylakoid membrane but in contrast to xanthophylls, carotenes contain no oxygen. Since synthesis of carotenoids is absent in animals, the only way for humans to ingest them is via plants (Adams et al., 1995; Schopfer and Brennicke, 2010; Bian et al., 2015). The human body is able to convert $\alpha$-carotene, $\beta$-carotene, and $\beta$-cryptoxanthin, each being a provitamin $\mathrm{A}$, into retinol. Retinol has the same action spectrum as vitamin A (Higdon, 2004). Grodstein et al. (2007) showed in a long-term study that the supplemental $\beta$-carotene every second day reduced cognitive decline in over 4052 male participants. Regarding human vision, Kvansakul et al. (2006) showed that a supplementation of lutein or zeaxanthin improved contrast acuity thresholds at high mesopic levels (dim light situations). According to Gallicchio et al. (2008) there is only a small and not statistically significant association between $\beta$-carotene and the decrease in development of lung cancer. However, carotenoids in general exhibit antioxidant properties (Esteban et al., 2014).

Regarding the carotenoid concentration in plants, Bian et al. (2015) summarize that particularly blue, red and UV-B light affect the accumulation of carotenoids in vegetables. Brazaitytë et al. showed that supplemental UV or blue light $(366,390$ or $402 \mathrm{~nm}$ ) decreases the carotenoid content in basil. Similarly, Ciurli et al. (2017) ascertained, that supplemental UV light from UV FL-Tubes does not promote accumulation of carotenoids.

In 2017, Liu et al. (2017) observed a slightly higher carotenoid accumulation in Lactuca sativa when adding green light and keeping the total PPFD constant. Exposing green leaf lettuce to
50\% red LED light and 50\% white light from FL-Tubes yielded a higher content of carotenoids than red and blue LED light (1:1) or sole FL-Tube light. With the use of white LEDs plus monochromatic LEDs, the same group obtained a maximum carotenoid concentration by using white plus red or white plus blue LEDs (Chen et al., 2016). For green leaf basil, Lobiuc et al. (2017) identified no significant change when altering the blue:red ratio concerning carotenoid accumulation. Samuolienë et al. (2016) exposed basil to blue and red LED light and investigated carotenoid content. They found it to be maximum when the amount of blue light ( $447 \mathrm{~nm}$ ) was low compared to red light and the intensity at $665 \mathrm{~nm}$ was higher than at $638 \mathrm{~nm}$. The results of Brazaitytë et al. (2016) showed, that the addition of $15 \mu \mathrm{mol} / \mathrm{m}^{2} / \mathrm{s}$ of green LED light $(520 \mathrm{~nm})$ increased the amount of carotenoids. Besides HPL, a blue:red ratio of 1:4 or 3:7 generated maximum accumulation of carotenoids in two cultivars of lamb's lettuce (Długosz-Grochowska et al., 2017). In contrast to that, Amoozgar et al. (2017) obtained a significant increase of carotenoids in lettuce using only blue and red light (3:7) compared to white LED light at a constant total PPFD. Exposing various microgreens (Amaranth, Cress, Mizuna and Purslane) to either sole blue or red light resulted in low carotenoid levels compared to applying both wavelengths together (Kyriacou et al., 2019). The group of Casierra-Posada found out that the highest amount of carotenoids in Beta vulgaris was obtained by implementing red colored or transparent filters in a greenhouse. However, blue or red colored filters also caused a lower total PPFD (CasierraPosada et al., 2015). Illuminating three different Brassicaceae microgreens with supplemental green, yellow or orange light, a promoting effect regarding accumulation of carotenoids was only 
TABLE 3 | Relative accumulation of flavonols after different treatments.

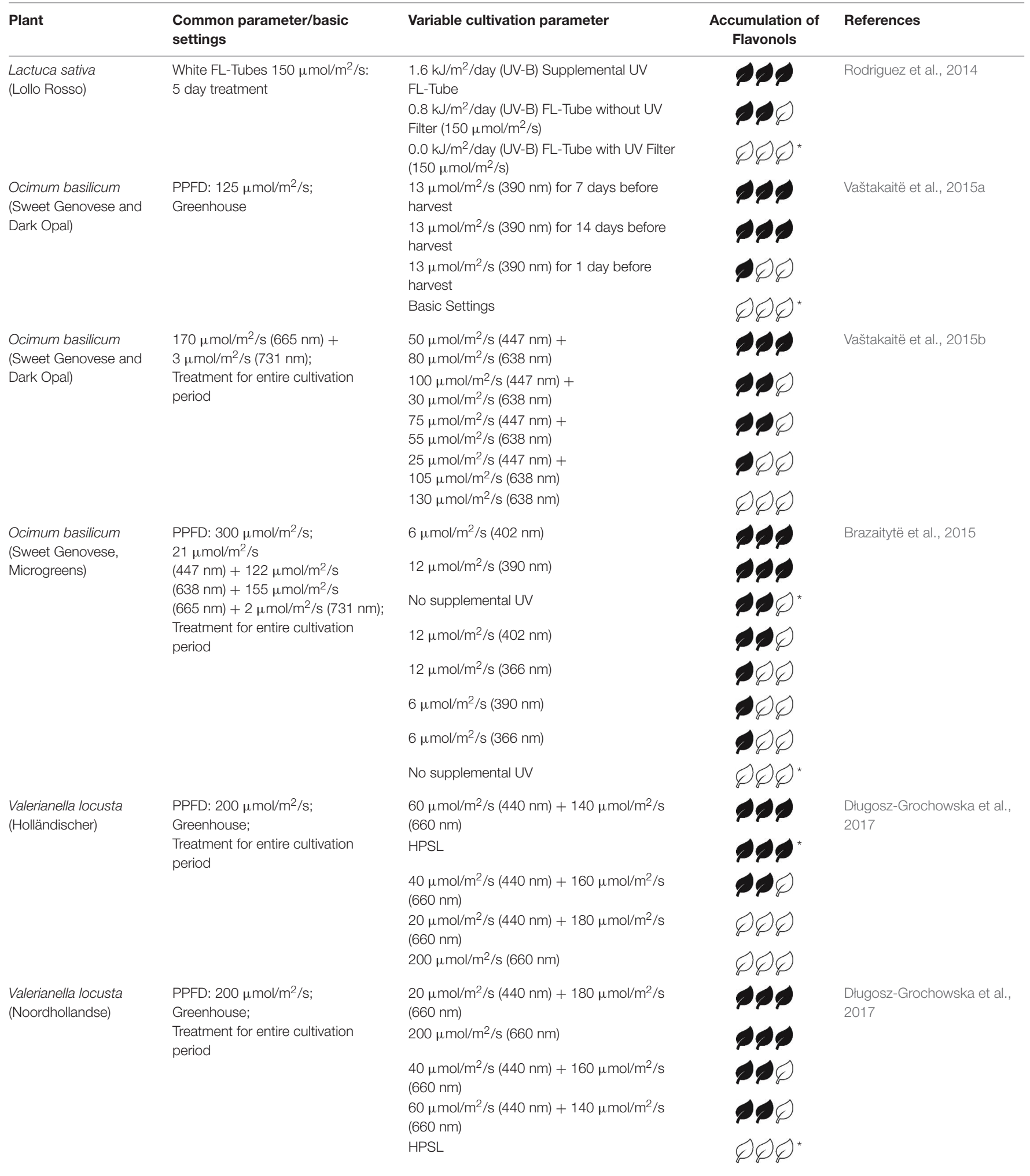

Three filled leaves indicate the highest value within one study, three unfilled leaves the lowest one. The scale is a quantitative one. HPSL: High Pressure Sodium Lamp; FL-Tube: Fluorescent Tube; PPFD: Total Photosynthetic Photon Flux Density; HIDL: High Intensity Discharge Lamp; DLI: Day Light Integral. The asterisk indicates the control group, if available. 
observed for mizuna. For broccoli and kohlrabi the control group displayed highest carotenoid levels (Samuolienë et al., 2019).

Keeping the blue:red ratio constant at 1:4 and altering the total PPFD, the maximum content of carotenoids in lettuce was found at $140 \mu \mathrm{mol} / \mathrm{m}^{2} / \mathrm{s}$ (Fu et al., 2017). Considering red and green lettuce, Ouzounis et al. (2015) showed maximum carotenoid concentration by supplementing daylight with blue LEDs $\left(80 \mu \mathrm{mol} / \mathrm{m}^{2} / \mathrm{s}\right)$ and HPSL $\left(90 \mu \mathrm{mol} / \mathrm{m}^{2} / \mathrm{s}\right)$ for $2 \mathrm{~h}$ in the evening.

According to the studies mentioned above, UV light does not promote the synthesis of carotenoids. In contrast to that, supplementary wavelengths in the green domain increase carotenoid accumulation, independent of light source (HPSL, FL tube or white LED). For green leaf lettuce this was shown e. g. with red LEDs plus FL tubes (Chen et al., 2014), however, the group of Liu et al. (2017) obtained decreased carotenoid content after illuminating lettuce with supplementary green light. Considering the optimal blue to red ratio for lettuce, Chen et al. (2016) obtained best results with a ratio of either 0.6 or 3 . Nevertheless, the majority of studies work with a blue:red ratio below 0.5 (Amoozgar et al., 2017; Fu et al., 2017). For basil, the ratio depends on variety. For detailed information see Table 2.

\section{Flavonols}

Besides quercetin and its glycoside rutin, kaempferol and myricetin are the most common flavonols in plants. Similar to carotenoids, flavonols show antioxidant properties (Böhm et al., 1998; Graf et al., 2005). Since they exhibit a strong absorbance in the short wavelength domain, they protect DNA and other UV sensible molecules against UV radiation (Bilger et al., 2001; Merzlyak et al., 2005; Rodriguez et al., 2014). Flavonols not only protect the plant against abiotic stresses (UV radiation, drought or heat) but also biotic stresses, such as herbivore and pathogen attack (Khalid et al., 2019). Compared to anthocyanins, flavonols are in general more stable molecules. This can be observed for example at the occasional color fading of strawberries (Böhm et al., 1998). Besides onions, broccoli or apples, various leafy greens contain flavonols (Graf et al., 2005; Vaštakaitë et al., 2015b; Długosz-Grochowska et al., 2017). Similar to anthocyanins, in humans they display various health benefits due to their ability of scavenging free radicals (Khalid et al., 2019).

Rodriguez et al. (2014) determined an increased concentration of flavonols in lettuce using supplemental UV FL-Tubes additional to sunlight and supplemental HPSL. Similarly, basil was exhibiting a higher flavonol content when being illuminated with $13 \mu \mathrm{mol} / \mathrm{m}^{2} / \mathrm{s}$ at $390 \mathrm{~nm}$ for 7 and 14 days before harvest (Vaštakaitë et al., 2015a). Brazaitytë et al. (2015) found out that supplemental 6 or $12 \mu \mathrm{mol} / \mathrm{m}^{2} / \mathrm{s}$ at a wavelength of 402 or $390 \mathrm{~nm}$, respectively, produced best results regarding flavonol index. Exposing basil to constant $170 \mu \mathrm{mol} / \mathrm{m}^{2} / \mathrm{s}$ at $665 \mathrm{~nm}$ and adjustable intensities at 447 and $638 \mathrm{~nm}$, the intensity providing best results was 50 and $80 \mu \mathrm{mol} / \mathrm{m}^{2} / \mathrm{s}$, respectively (Vaštakaitë et al., 2015b).

In contrast, Długosz-Grochowska et al. (2017) obtained different results using the same wavelength and ratios for two cultivars of lamb's lettuce. For the first cultivar, illumination with HPSL or a ratio of blue to red of 3:7 showed best effects. The second one had maximum flavonol content at a blue:red ratio of
1:9 or no blue light and minimum content after illumination with HPSL (Długosz-Grochowska et al., 2017).

The concentration of both flavonols, quercetin and its glycoside rutin, were investigated in basil with supplemental UV$\mathrm{B}$ irradiation. Best results for both were obtained at an irradiance of $3.6 \mathrm{~W} / \mathrm{m}^{2}$ for a photoperiod of $8 \mathrm{~h}$. For $10 \mathrm{~h}$ exposure, minimal rutin and quercetin content were detected (Ghasemzadeh et al., 2016). The rutin content in lamb's lettuce was shown to be highest after applying a blue:red ratio of 1:1. Keeping the total PPFD constant, less blue light, HPSL, cold or warm white LEDs yielded lower contents (Długosz-Grochowska et al., 2016).

The underlying blue to red ratio considering flavonoid accumulation is species dependent and lies in the range between 1:1 and no blue light at all. A promoting factor for accumulation of flavonols in leafy greens is supplementary light in the UV range. In contrast to anthocyanins and carotenoids accumulation, basil shows a positive correlation regarding supplementary UV light and the accumulation of flavonols. In total, the applied PPFD for most leafy greens is in the range of 150 $300 \mu \mathrm{mol} / \mathrm{m}^{2} / \mathrm{s}$. For detailed information see Table 3 .

\section{DISCUSSION}

The present work gives an overview of the latest results and reveals tendencies concerning the accumulation of selected secondary metabolites triggered through light. In order to address corresponding photoreceptors, specific wavelength bands must be provided. Due to its monochromatic characteristics, its rapid advancement and consequent cost reduction, LED technology is well suited for conducting precise cultivation experiments and later on cultivation conditions.

When comparing optimal light conditions regarding the accumulation of anthocyanins between those for carotenoids or flavonols, we conclude blue:red ratios being smaller than 1 to be optimal. For carotenoids and especially for flavonols, the amount of blue light can decrease to 0 - depending on the specific type of phenolic compound and plant species. In contrast to anthocyanins, supplementary green light promotes the accumulation of carotenoids in most of leafy greens. This coincides with their absorption maximum in the green light domain. In general, for all three secondary metabolites UV light is a promoting factor, except for the accumulation of anthocyanins in basil.

Since the aim often is to increase nutritional value and quality of crops, not only levels of certain secondary metabolites but also their biological activity is an important parameter to investigate. Studies, which investigated for example the free radial scavenging activity, in general showed a positive correlation with levels of either flavonoids or carotenoids. For basil, Samuolienë et al. (2016) found an increased ability of scavenging free radicals when applying either a relatively high or low ratio of 638 to $665 \mathrm{~nm}$. Red light increased the free radical scavenging activity in green basil and blue light in red basil cultivars (Lobiuc et al., 2017). Within two varieties of Valerianella locusta the free radical scavenging activity differed under different light conditions. For Holländischer, increased activity was detected 
after supplementary blue light, for Noordhollandse no significant changes were measured, except for illumination with relatively high red light intensities (Długosz-Grochowska et al., 2017). Supplementary far-red light or an increased blue:red ratio enhances antioxidant activity in green leaf and red leaf lettuce, respectively (Son and Oh, 2015; Lee et al., 2016).

Besides redundant and overlapping results, in many cases a comparison between multiple studies is challenging. This is mainly due to different experimental setups considering not only light conditions but also other environmental parameters or plant varieties. Furthermore, the use and mixture of different units, such as $\mathrm{W} / \mathrm{m}^{2}$, $\mu \mathrm{mol} / \mathrm{m}^{2} / \mathrm{s}$ or $\%$ complicate comparability. In order to increase comparability, more uniform standards regarding cultivation conditions are required. Consequently, future work will help to detect further correlations between light and the accumulation of secondary metabolites or their biological activity with increasing certainty. Those specifically tailored light spectra will enable growers to produce high quality crops not only for human nutrition but also for medicinal purposes in an efficient manner. In order to be flexible regarding cultivar variety and having the ability to grow products of high nutritional value,

\section{REFERENCES}

Adams, W. W., Demmig-Adams, B., Verhoeven, A. S., and Barker, D. H. (1995). 'Photoinhibition' during winter stress: involvement of sustained Xanthophyll cycle-dependent energy dissipation. Aust. J. Plant Physiol. 22, 261-276. doi: 10.1071/PP9950261

Ahmad, M., and Cashmore, A. R. (1993). HY4 gene of A. thaliana encodes a protein with characteristics of a blue-light photoreceptor. Nature 366, 162-166. doi: $10.1038 / 366162 \mathrm{a} 0$

Amoozgar, A., Mohammadi, A., and Sabzalian, M. R. (2017). Impact of lightemitting diode irradiation on photosynthesis, phytochemical composition and mineral element content of lettuce cv. Grizzly. Photosynthetica 55, 85-95. doi: 10.1007/s11099-016-0216-8

Andersen, Ø. M., and Jordheim, M. (2010). Anthocyanins. Encycl. Life Sci. 358:47. doi: 10.1002/9780470015902.a0001909.pub2

Bagchi, D., Garg, A., Krohn, R. L., Bagchi, M., Bagchi, D. J., Balmoori, J., et al. (1998). Protective effects of grape seed proanthocyanidins and selected antioxidants against TPA-induced hepatic and brain lipid peroxidation and DNA fragmentation, and peritoneal macrophage activation in mice. Gen. Pharmacol. 30, 771-776. doi: 10.1016/S0306-3623(97)00332-7

Barrero, J. M., Downie, A. B., Xu, Q., and Gubler, F. (2014). A role for barley CRYPTOCHROME1 in light regulation of grain dormancy and germination. Plant Cell 26, 1094-1104. doi: 10.1105/tpc.113.121830

Bian, Z. H., Yang, Q. C., and Liu, W. K. (2015). Effects of light quality on the accumulation of phytochemicals in vegetables produced in controlled environments: a review. J. Sci. Food Agric. 95, 869-877. doi: 10.1002/jsfa.6789

Bieza, K., and Lois, R. (2001). An Arabidopsis mutant tolerant to lethal ultraviolet-b levels shows constitutively elevated accumulation of flavonoids and other Phenolics1. Plant Physiol. 126, 1105-1115. doi: 10.1104/pp.126.3. 1105

Bilger, W., Johnsen, T., and Schreiber, U. (2001). UV-excited chlorophyll fluorescence as a tool for the assessment of UV-protection by the epidermis of plants. J. Exp. Bot. 52, 2007-2014.

Böhm, H., Boeing, H., Hempel, J., Raab, B., and Kroke, A. (1998). Flavonole, Flavone und Anthocyane als natürliche Antioxidantien der Nahrung und ihre mögliche Rolle bei der Prävention chronischer Erkrankungen. Eur. J. Nutr. 37, 147-163. doi: 10.1007/PL00007376

Bouly, J.-P., Schleicher, E., Dionisio-Sese, M., Vandenbussche, F., van der Straeten, D., Bakrim, N., et al. (2007). Cryptochrome blue light photoreceptors are activated through interconversion of flavin redox states. J. Biol. Chem. 282, 9383-9391. doi: 10.1074/jbc.M609842200 producers need to invest in adjustable light fixtures, which cover more than PAR domain.

\section{AUTHOR CONTRIBUTIONS}

FT conceptualized and designed the work, collected, analyzed, and interpreted the data, drafted the manuscript. AS-S and DS collected the data, contributed to critical revision of the manuscript. VK and GD contributed to critical revision of the manuscript, approved the final version to be published.

\section{FUNDING}

This study was partially supported by the Federal Ministry of Education and Research (BMBF) through the program Agricultural Systems of the Future in the framework of the "National Research Strategy BioEconomy 2030" under grant No. 031B0728A "SUSKULT - Development of a Sustainable Cultivation System of Resilient Metropolitan Regions."

Brazaitytë, A., Viršilë, A., Jankauskienë, J., Sakalauskienë, S., Samuolienë, G., Sirtautas, R., et al. (2015). Effect of supplemental UV-A irradiation in solidstate lighting on the growth and phytochemical content of microgreens. Int. Agrophys. 29, 13-22. doi: 10.1515/intag-2015-0004

Brazaitytë, A., Viršilë, A., Samuolienë, G., Jankauskienë, J., Sakalauskienë, S., Sirtautas, R., et al. (2016). Light quality: growth and nutritional value of microgreens under indoor and greenhouse conditions. Acta Hortic. 1134, 277-284. doi: 10.17660/ActaHortic.2016.1134.37

Brglez Mojzer, E., Knez Hrnèiè, M., Škerget, M., Knez, Ž., and Bren, U. (2016). Polyphenols: extraction methods, antioxidative action, bioavailability and anticarcinogenic effects. Molecules 21:E901. doi: 10.3390/molecules21070901

Casal, J. J. (2000). Phytochromes, cryptochromes, phototropin: photoreceptor interactions in plants. Photochem. Photobiol. 71, 1-11. doi: 10.1562/00318655(2000)0710001pcppii2.0.co2

Casierra-Posada, F., Zapata-Casierra, E., and Blanke, M. M. (2015). Accelerating the growth and increasing the nutritional value of chard (Beta vulgaris L. var. cicla) by applying yellow coloured filters. Eur. J. Hortic. Sci. 80, 263-270. doi: 10.17660/eJHS.2015/80.6.1

Castañeda-Ovando, A., Pacheco-Hernández, M. D. L., Páez-Hernández, M. E., Rodríguez, J. A., and Galán-Vidal, C. A. (2009). Chemical studies of anthocyanins: a review. Food Chem. 113, 859-871. doi: 10.1016/j.foodchem. 2008.09.001

Chen, X.-L., Guo, W.-Z., Xue, X.-Z., Wang, L.-C., and Qiao, X.-J. (2014). Growth and quality responses of 'Green Oak Leaf' lettuce as affected by monochromic or mixed radiation provided by fluorescent lamp (FL) and light-emitting diode (LED). Sci. Hortic. 172, 168-175. doi: 10.1016/j.scienta.2014.04.009

Chen, X.-L., Xue, X.-Z., Guo, W.-Z., Wang, L.-C., and Qiao, X.-J. (2016). Growth and nutritional properties of lettuce affected by mixed irradiation of white and supplemental light provided by light-emitting diode. Sci. Hortic. 200, 111-118. doi: 10.1016/j.scienta.2016.01.007

Chen, X.-L., Yang, Q.-C., Song, W.-P., Wang, L.-C., Guo, W.-Z., and Xue, X.Z. (2017). Growth and nutritional properties of lettuce affected by different alternating intervals of red and blue LED irradiation. Sci. Hortic. 223, 44-52. doi: 10.1016/j.scienta.2017.04.037

Ciurli, A., Huarancca Reyes, T., and Guglielminetti, L. (2017). Commercial advantages on basil architecture by ultraviolet-B irradiation. Adv. Hortic. Sci. 31, 215-221. doi: 10.13128/AHS-20460

Coffey, A., Prinsen, E., Jansen, M. A. K., and Conway, J. (2017). The UVB photoreceptor UVR8 mediates accumulation of UV-absorbing pigments, but not changes in plant morphology, under outdoor conditions. Plant Cell Environ. 40, 2250-2260. doi: 10.1111/pce.13025 
Cope, K. R., and Bugbee, B. (2013). Spectral effects of three types of white lightemitting diodes on plant growth and development: absolute versus relative amounts of blue light. HortScience 48, 504-509. doi: 10.21273/HORTSCI.48. 4.504

Deutsches Institut für Normung (2018). Strahlungsphysik im Optischen Bereich und Lichttechnik - Teil 10: Photobiologisch Wirksame Strahlung, Größen, Kurzzeichen und Wirkungsspektren. 5031-10. Berlin: Beuth Verlag.

Devlin, P. F. (2000). Cryptochromes are required for phytochrome signaling to the circadian clock but not for rhythmicity. Plant Cell 12, 2499-2510. doi: 10.1105/tpc.12.12.2499

Długosz-Grochowska, O., Kołton, A., and Wojciechowska, R. (2016). Modifying folate and polyphenol concentrations in Lamb's lettuce by the use of LED supplemental lighting during cultivation in greenhouses. J. Funct. Foods 26, 228-237. doi: 10.1016/j.jff.2016.07.020

Długosz-Grochowska, O., Wojciechowska, R., Kruczek, M., and Habela, A. (2017). Supplemental lighting with LEDs improves the biochemical composition of two Valerianella locusta (L.) cultivars. Hortic. Environ. Biotechnol. 58, 441-449. doi: 10.1007/s13580-017-0300-4

Dou, H., Niu, G., Gu, M., and Masabni, J. G. (2018). Responses of sweet basil to different daily light integrals in photosynthesis, morphology, yield, and nutritional quality. HortScience 53, 496-503. doi: 10.21273/HORTSCI12785- 17

Esteban, R., Fleta-Soriano, E., Buezo, J., Míguez, F., Becerril, J. M., and GarcíaPlazaola, J. I. (2014). Enhancement of zeaxanthin in two-steps by environmental stress induction in rocket and spinach. Food Res. Int. 65, 207-214. doi: 10.1016/ j.foodres.2014.05.044

Evans, C. S. (1991). Methods in plant biochemistry: 1. plant phenolics. Phytochem. Anal. 2:48. doi: 10.1002/pca.2800020110

Folta, K. M. (2004). Green light stimulates early stem elongation, antagonizing light-mediated growth inhibition. Plant Physiol. 135, 1407-1416. doi: 10.1104/ pp.104.038893

Folta, K. M., and Carvalho, S. D. (2015). Photoreceptors and control of horticultural plant traits. HortScience 50, 1274-1280. doi: 10.21273/hortsci.50. 9.1274

Folta, K. M., and Maruhnich, S. A. (2007). Green light: a signal to slow down or stop. J. Exp. Bot. 58, 3099-3111. doi: 10.1093/jxb/erm130

Folta, K. M., and Spalding, E. P. (2001). Unexpected roles for cryptochrome 2 and phototropin revealed by high-resolution analysis of blue light-mediated hypocotyl growth inhibition. Plant J. 26, 471-478. doi: 10.1046/j.1365-313x. 2001.01038.x

Fox, A. R., Soto, G. C., Jones, A. M., Casal, J. J., Muschietti, J. P., and Mazzella, M. A. (2012). cryl and GPA1 signaling genetically interact in hook opening and anthocyanin synthesis in Arabidopsis. Plant Mol. Biol. 80, 315-324. doi: 10.1007/s11103-012-9950-x

Frankhauser, C., and Chory, J. (1997). Light control of plant development. Annu. Rev. Cell Dev. Biol. 13, 203-229.

Fu, Y., Li, H., Yu, J., Liu, H., Cao, Z., Manukovsky, N. S., et al. (2017). Interaction effects of light intensity and nitrogen concentration on growth, photosynthetic characteristics and quality of lettuce (Lactuca sativa L Var. youmaicai). Sci. Hortic. 214, 51-57. doi: 10.1016/j.scienta.2016.11.020

Fuller, K. K., Dunlap, J. C., and Loros, J. J. (2016). Fungal light sensing at the bench and beyond. Adv. Genet. 96, 1-51. doi: 10.1016/bs.adgen.2016.08.002

Gallicchio, L., Boyd, K., Matanoski, G., Tao, X. G., Chen, L., Lam, T. K., et al. (2008). Carotenoids and the risk of developing lung cancer: a systematic review. Am. J. Clin. Nutr. 88, 372-383. doi: 10.1093/ajcn/88.2.372

Ghasemzadeh, A., Ashkani, S., Baghdadi, A., Pazoki, A., Jaafar, H. Z. E., and Rahmat, A. (2016). Improvement in flavonoids and phenolic acids production and pharmaceutical quality of sweet basil (Ocimum basilicum L.) by UltravioletB Irradiation. Molecules 21:E1203. doi: 10.3390/molecules21091203

Goto, E., Hayashi, K., Furuyama, S., Hikosaka, S., and Ishigami, Y. (2016). Effect of UV light on phytochemical accumulation and expression of anthocyanin biosynthesis genes in red leaf lettuce. Acta Hortic. 1134, 179-186. doi: 10.17660/ ActaHortic.2016.1134.24

Goyal, A., Karayekov, E., Galvão, V. C., Ren, H., Casal, J. J., and Fankhauser, C. (2016). Shade promotes phototropism through phytochrome B-controlled auxin production. Curr. Biol. 26, 3280-3287. doi: 10.1016/j.cub.2016.10.001

Graf, B. A., Milbury, P. E., and Blumberg, J. B. (2005). Flavonols, flavones, flavanones, and human health: epidemiological evidence. J. Med. Food 8, 281-290. doi: 10.1089/jmf.2005.8.281
Grodstein, F., Kang, J. H., Glynn, R. J., Cook, N. R., and Gaziano, M. (2007). A randomized trial of beta carotene supplementation and cognitive function in men: the physicians' health study II. Arch. Intern. Med. 20, 2184-2190. doi: 10.1001/archinte.167.20.2184

Guo, H., Yang, H., Mockler, T. C., and Lin, C. (1998). Regulation of flowering time by Arabidopsis photoreceptors. Science 279, 1360-1363. doi: 10.1126/science. 279.5355 .1360

Higdon, J. (2004). Phytochemicals. Available online at: http://lpi.oregonstate.edu/ mic/dietary-factors/phytochemicals (accessed July 05, 2018).

Kang, X., and Ni, M. (2006). Arabidopsis SHORT HYPOCOTYL UNDER BLUE1 contains SPX and EXS domains and acts in cryptochrome signaling. Plant Cell 18, 921-934. doi: 10.1105/tpc.105.037879

Khalid, M., Saeed-ur-Rahman, Bilal, M., and Huang, D.-F. (2019). Role of flavonoids in plant interactions with the environment and against human pathogens - A review. J. Integr. Agric. 18, 211-230. doi: 10.1016/S20953119(19)62555-4

Khoo, H. E., Azlan, A., Tang, S. T., and Lim, S. M. (2017). Anthocyanidins and anthocyanins: colored pigments as food, pharmaceutical ingredients, and the potential health benefits. Food Nutr. Res. 61:1361779. doi: 10.1080/16546628. 2017.1361779

Kong, J.-M., Chia, L.-S., Goh, N.-K., Chia, T.-F., and Brouillard, R. (2003). Analysis and biological activities of anthocyanins. Phytochemistry 64, 923-933. doi: 10. 1016/S0031-9422(03)00438-2

Kozai, T., Fujiwara, K., and Runkle, E. S. (eds) (2016). LED Lighting for Urban Agriculture. Singapore: Springer.

Kvansakul, J., Rodriguez-Carmona, M., Edgar, D. F., Barker, F. M., Köpcke, W., Schalch, W., et al. (2006). Supplementation with the carotenoids lutein or zeaxanthin improves human visual performance. Ophthalmic Physiol. Opt. 26, 362-371. doi: 10.1111/j.1475-1313.2006.00387.x

Kyriacou, M. C., El-Nakhel, C., Pannico, A., Graziani, G., Soteriou, G. A., Giordano, M., et al. (2019). Genotype-specific modulatory effects of select spectral bandwidths on the nutritive and phytochemical composition of microgreens. Front. Plant Sci. 10:1501. doi: 10.3389/fpls.2019.01501

Lee, M.-J., Son, K.-H., and Oh, M.-M. (2016). Increase in biomass and bioactive compounds in lettuce under various ratios of red to far-red LED light supplemented with blue LED light. Hortic. Environ. Biotechnol. 57, 139-147. doi: 10.1007/s13580-016-0133-6

Liu, H., Fu, Y., and Wang, M. (2017). Green light enhances growth, photosynthetic pigments and $\mathrm{CO}_{2}$ assimilation efficiency of lettuce as revealed by 'knock out' of the 480-560 nm spectral waveband. Photosynthetica 55, 144-152. doi: 10.1007/ s11099-016-0233-7

Lobiuc, A., Vasilache, V., Pintilie, O., Stoleru, T., Burducea, M., Oroian, M., et al. (2017). ). Blue and red LED illumination improves growth and bioactive compounds contents in acyanic and cyanic Ocimum basilicum L. microgreens. Molecules 22:2111. doi: 10.3390/molecules22122111

Lu, N., Bernardo, E. L., Tippayadarapanich, C., Takagaki, M., Kagawa, N., and Yamori, W. (2017). Growth and accumulation of secondary metabolites in perilla as affected by photosynthetic photon flux density and electrical conductivity of the nutrient solution. Front. Plant Sci. 8:708. doi: 10.3389/fpls. 2017.00708

Mao, J., Zhang, Y.-C., Sang, Y., Li, Q.-H., and Yang, H.-Q. (2005). A role for Arabidopsis cryptochromes and COP1 in the regulation of stomatal opening. Proc. Natl. Acad. Sci. U.S.A. 102, 12270-12275. doi: 10.1073/pnas.05010 11102

Massa, G., Graham, T., Haire, T., Flemming, C. II, Newsham, G., and Wheeler, R. M. (2015). Light-emitting diode light transmission through leaf tissue of seven different crops. HortScience 50, 501-506. doi: 10.21273/hortsci.50.3.501

McCree, K. J. (1972). The action spectrum, absorptance and quantum yield of photosynthetisis in crop plants. Agric. Meterol. 9, 191-216. doi: 10.1016/00021571(71)90022-7

Merzlyak, M. N., Solovchenko, A. E., Smagin, A. I., and Gitelson, A. A. (2005). Apple flavonols during fruit adaptation to solar radiation: spectral features and technique for non-destructive assessment. J. Plant Physiol. 162, 151-160. doi: 10.1016/j.jplph.2004.07.002

Mosadegh, H., Trivellini, A., Ferrante, A., Lucchesini, M., Vernieri, P., and Mensuali, A. (2018). Applications of UV-B lighting to enhance phenolic accumulation of sweet basil. Sci. Hortic. 229, 107-116. doi: 10.1016/j.scienta. 2017.10.043 
Nicole, C. C. S., Charalambous, F., Martinakos, S., van de Voort, S., Li, Z., Verhoog, M., et al. (2016). Lettuce growth and quality optimization in a plant factory. Acta Hortic. 1134, 231-238. doi: 10.17660/ActaHortic.2016.1134.31

Onyilagha, J. C., Lazorko, J., Gruber, M. Y., Soroka, J. J., and Erlandson, M. A. (2004). Effect of flavonoids on feeding preference and development of the crucifer pest Mamestra configurata Walker. J. Chem. Ecol. 30, 109-124. doi: 10.1023/B:JOEC.0000013185.62475.65

Ouzounis, T., Razi Parjikolaei, B., Fretté, X., Rosenqvist, E., and Ottosen, C.O. (2015). Predawn and high intensity application of supplemental blue light decreases the quantum yield of PSII and enhances the amount of phenolic acids, flavonoids, and pigments in Lactuca sativa. Front. Plant Sci. 6:19. doi: 10.3389/fpls.2015.00019

Pagare, S., Bhatia, M., Tripathi, N., Pagare, S., and Bansal, Y. K. (2015). Secondary metabolites of plants and their role: overview. Curr. Trends Biotechnol. Pharm. 9, 294-305.

Pedro, A. C., Moreira, F., Granato, D., and Rosso, N. D. (2016). Extraction of bioactive compounds and free radical scavenging activity of purple basil (Ocimum basilicum L.) leaf extracts as affected by temperature and time. An. Acad. Bras. Cienc. 88, 1055-1068. doi: 10.1590/0001-3765201620150197

Pérez-López, U., Miranda-Apodaca, J., Muñoz-Rueda, A., and Mena-Petite, A. (2015). Interacting effects of high light and elevated $\mathrm{CO}_{2}$ on the nutraceutical quality of two differently pigmented Lactuca sativa cultivars (Blonde of Paris Batavia and Oak Leaf). Sci. Hortic. 191, 38-48. doi: 10.1016/j.scienta.2015. 04.030

Pérez-López, U., Sgherri, C., Miranda-Apodaca, J., Micaelli, F., Lacuesta, M., Mena-Petite, A., et al. (2018). Concentration of phenolic compounds is increased in lettuce grown under high light intensity and elevated $\mathrm{CO}_{2}$. Plant Physiol. Biochem. 123, 233-241. doi: 10.1016/j.plaphy.2017.12.010

Popov, V. N., Eprintsev, A. T., Fedorin, D. N., and Igamberdiev, A. U. (2010). Succinate dehydrogenase in Arabidopsis thaliana is regulated by light via phytochrome A. FEBS Lett. 584, 199-202. doi: 10.1016/j.febslet.2009. 11.057

Rodriguez, C., Torre, S., and Solhaug, K. A. (2014). Low levels of ultraviolet-B radiation from fluorescent tubes induce an efficient flavonoid synthesis in Lollo Rosso lettuce without negative impact on growth. Acta Agric. Scand. Sect. B Soil Plant Sci. 64, 178-184. doi: 10.1080/09064710.2014.905623

Samanta, A., Das, S. K., and Das Gouranga. (2011). Roles of flavonoids in plants. Int. J. Pharm. Sci. Tech. 6, 12-35.

Samuolienë, G., Brazaityte, A., Viršilë, A., Jankauskienë, J., Sakalauskienë, S., and Duchovskis, P. (2016). Red light-dose or wavelength-dependent photoresponse of antioxidants in herb Microgreens. PLoS One 11:e0163405. doi: 10.1371/ journal.pone.0163405

Samuolienë, G., Brazaitytë, A., Viršilë, A., Miliauskienë, J., Vaštakaitë-Kairienë, V., and Duchovskis, P. (2019). Nutrient levels in Brassicaceae Microgreens increase under tailored light-emitting diode spectra. Front. Plant Sci. 10:1475. doi: 10.3389/fpls.2019.01475

Samuolienë, G., Viršilë, A., Brazaitytë, A., Jankauskienë, J., Sakalauskienë, S., Vaštakaitë, V., et al. (2017). Blue light dosage affects carotenoids and tocopherols in microgreens. Food Chem. 228, 50-56. doi: 10.1016/j.foodchem. 2017.01.144

Schopfer, P., and Brennicke, A. (2010). Pflanzenphysiologie. Heidelberg: Spektrum Akademischer Verlag.

Siddiqui, M. W., and Prasad, K. (eds) (2017). Plant Secondary Metabolites: Giovanni Geller with Jon W. Thompson. Oakville, ON: Apple Academic Press.

Son, K.-H., and Oh, M.-M. (2015). Growth, photosynthetic and antioxidant parameters of two lettuce cultivars as affected by red, green, and blue lightemitting diodes. Hortic. Environ. Biotechnol. 56, 639-653. doi: 10.1007/s13580015-1064-3

Takemiya, A., Inoue, S.-I., Doi, M., Kinoshita, T., and Shimazaki, K.-I. (2005). Phototropins promote plant growth in response to blue light in low light environments. Plant Cell 17, 1120-1127. doi: 10.1105/tpc.104.030049

Tattini, M., Landi, M., Brunetti, C., Giordano, C., Remorini, D., Gould, K. S., et al. (2014). Epidermal coumaroyl anthocyanins protect sweet basil against excess light stress: multiple consequences of light attenuation. Physiol. Plant. 152, 585-598. doi: 10.1111/ppl.12201

Tazawa, S. (1999). Effects of various radiant sources on plant growth: part 1. Jpn. Agric. Res. Q. 163-176.

Tilbrook, K., Arongaus, A. B., Binkert, M., Heijde, M., Yin, R., and Ulm, R. (2013). The UVR8 UV-B photoreceptor: perception, signaling and response. Arabidopsis Book 11:e0164. doi: 10.1199/tab.0164

Vaštakaitë, V., Viršilë, A., Brazaitytë, A., Samuolienë, G., Jankauskienë, J., Sirtautas, R., et al. (2015a). "The effect of UV-A supplemental lighting on antioxidant properties of ocimum basilicum 1. microgreens in greenhouse," in Proceedings of the 7th International Scientific Conference Rural Development 2015, eds A. Raupelienë and J. Eerniauskienë (Akademija: Aleksandras Stulginskis University).

Vaštakaitë, V., Viršilë, A., Samuolienë, G., Jankauskienë, J., Sirtautas, R., Dabašinskas, L., et al. (2015b). The effect of blue light dosage on growth and antioxidant properties of microgreens. Sodin. Daržininkystė 34, 25-35.

Wang, Y., and Folta, K. M. (2013). Contributions of green light to plant growth and development. Am. J. Bot. 100, 70-78. doi: 10.3732/ajb.1200354

Zhang, Y., Xu, S., Cheng, Y., Peng, Z., and Han, J. (2018). Transcriptome profiling of anthocyanin-related genes reveals effects of light intensity on anthocyanin biosynthesis in red leaf lettuce. PeerJ 6:e4607. doi: 10.7717/peerj.4607

Conflict of Interest: The authors declare that the research was conducted in the absence of any commercial or financial relationships that could be construed as a potential conflict of interest.

Copyright (c) 2020 Thoma, Somborn-Schulz, Schlehuber, Keuter and Deerberg. This is an open-access article distributed under the terms of the Creative Commons Attribution License (CC BY). The use, distribution or reproduction in other forums is permitted, provided the original author(s) and the copyright owner(s) are credited and that the original publication in this journal is cited, in accordance with accepted academic practice. No use, distribution or reproduction is permitted which does not comply with these terms. 